\title{
0 poder da representação: a relação entre Executivo e Legislativo na política imperial de meados do século XIX
}

DOI

http://dx.doi.org/10.1590/2236-463320161304
Debating projects, making a State: the Executive and Legislative relations on Empire politics, middle 19th century

\section{Vitor Marcos Gregório \\ Universidade Federal de São Paulo - UNIFESP, São Paulo - SP, Brasil. Instituto Federal do Paraná - União da Vitória, Paraná - PR, Brasil.}

\begin{abstract}
Resumo
Este artigo tem por objetivo analisar brevemente dois momentos da dinâmica política brasileira de meados do século XIX: os debates em torno da criação da província do Paraná, em 1843; e os debates em torno do estabelecimento de linhas de navegação no rio Amazonas, em 1853. A partir da constatação de que a relação entre os poderes Executivo e Legislativo ao longo destes debates não se baseava na submissão de deputados e senadores às determinações e opiniões emanadas do ministério, é feita a indicação da necessidade de se repensar o processo político do império brasileiro sobre novas bases, que confiram maior importância ao parlamento na formulação e adoção de políticas reputadas fundamentais para o conjunto da nação.
\end{abstract}

\begin{abstract}
This paper aims to analyze two specific moments of the Brazilian political dynamics in the middle of Nineteenth century: the debates about the emancipation of the Paraná province, in 1843; and the debates about Amazon River steam navigation, in 1853. Starting from the fact that the relationship between Executive and Legislative powers throughout this debates was not based in a parliamentary automatic submission to the determinations and orders previously sent by ministers, the need to rethink the political process in the Empire of Brazil on a new basis is proposed, one which grant greater importance to Parliament in formulation and adoption of very important decisions for the nation as a whole.
\end{abstract}

Palavras-chave

Brasil Império; Parlamento; Poder Executivo; Poder Legislativo; Política.

Keywords

Empire of Brazil; Parliament; Executive Power; Legislative Power; Politics. 
URUGUAI, Visconde do. Ensaio sobre o Direito Administrativo. In: CARVALHO, José Murilo de (org.). Paulino José Soares de Sousa, Visconde do Uruguai. São Paulo: Editora 34, 2002.

2

SÃO VICENTE, Marquês de. Direito Público Brasileiro e Análise da Constituição do Império. In: KUGELMAS, Eduardo (org.). José Antônio Pimenta Bueno, Marquês de São Vicente. São Paulo: Editora 34, 2002

VASCONCELOS, Zacarias de Góis e. Da Natureza e Limites do Poder Moderador. In: OLIVEIRA, Cecilia Helena de Salles (org.). Zacarias de Góis e Vasconcelos. São Paulo: Editora 34, 2002.
DOLHNIKOFF, Miriam; MAIA, Francisleide; SAEZ, Hernán Lara; SALES, Pedro Paulo Moreira; GREGÓRIO, Vitor Marcos. Representação política no Império: crítica à ideia do falseamento institucional. In: LAVALLE, Adrian Gurza (org.). O horizonte da política: questões emergentes e agendas de pesquisa. São Paulo: Editora Unesp/ CEBRAP. CEM, 2012, pp. 97-141.
Ao longo de todo o século XIX, foram comuns as afirmações feitas por políticos brasileiros de que estavam se esforçando para construir e consolidar um sistema representativo no pais. Para além das clássicas formulações neste sentido de Paulino José Soares de Sousa', de José Antônio Pimenta Bueno ${ }^{2}$ e de Zacarias de Góis e Vasconcelos ${ }^{3}$ - apenas para tratar de três das obras mais emblemáticas acerca do sistema político imperial -, não é de modo algum difícil encontrar nos discursos parlamentares proferidos ao longo de todo o período, bem como nos relatórios ministeriais apresentados anualmente a deputados gerais e senadores, afirmações eloquentes que caminham na mesma direção.

De fato, durante a leitura dos anais que contém a transcrição das falas proferidas no parlamento imperial, salta à vista, rotineiramente, a preocupação com a representação da nação e com o modo como esta deveria ser exercida, com o papel a ser desempenhado por deputados e senadores na construção e consolidação do Estado brasileiro, e com os limites que deveriam ser respeitados pelas respectivas esferas do poder imperial durante o desenrolar deste complexo processo. Não raro, do encontro de pontos de vista diferentes acerca desses e de outros temas, emergiram debates acalorados que precisaram ser contidos por diversos meios, fato que por si só indica a importância votada por estes homens à questão da representação política em suas múltiplas determinações e com seus inúmeros desdobramentos. Tratava-se, na visão desses atores históricos, de um modelo monárquico oriundo da Europa e originário das experiências pós-revolucionárias inglesa e francesa, ao qual a partir de então passou a ser associado um ideal de representação política dos diversos setores da sociedade através do parlamento, local por excelência dos debates de temas que atingissem, em algum grau, seus interesses ${ }^{4}$.

A constatação desta importância pela historiografia, contudo, é bastante recente e está longe de ser unanimidade. Predomina ainda no meio acadêmico, quando se trata de analisar a política imperial, certo pessimismo em relação à ideia de que funcionava ali, efetivamente, um sistema representativo tal qual o defendido pelos políticos contemporâneos. Para boa parte dos historiadores que se debruçaram sobre o período, a presença da escravidão, a ocorrência de fraudes e violências na realização das eleições, além da existência de um Poder Moderador que possuía a prerrogativa de dissolver a Câmara dos Deputados quando reputasse necessário, levam à necessidade de desconfiar da real existência de tal sistema. Ele estaria consagrado nas leis, estaria formulado nos lábios daqueles supostamente empenhados em sua construção, mas não possuiria existência real no cotidiano político do Brasil oitocentista.

De acordo com tal ponto de vista, cabia exclusivamente ao imperador elencar as prioridades e tomar as decisões necessárias à condução da nação ao longo de todo o período, devendo seus conselheiros mais próximos oferecer sugestões acerca das ações a serem adotadas e cabendo a seus ministros garantir, da melhor forma possivel, o atendimento das determinações recebidas do palácio de São Cristóvão. Dentro deste arranjo institucional, a função dos membros do parlamento seria tão somente referendar os projetos apresentados pelo Poder Executivo, conferindo ao regime imperial uma fachada de legitimidade que, de outra forma, estaria irremediavelmente prejudicada. Trata-se da tese do poder pessoal do imperador, segundo a qual o monarca se valia das prerrogativas do Poder Moderador para nomear ministérios sem qualquer preocupação com a maioria parlamentar e, no caso de 
esta se tornar hostil ao governo, para dissolvê-la convocando novas eleições. Neste momento, graças ao amplo recurso à fraude eleitoral e ao fato de que caberia ao novo gabinete recém nomeado organizar o pleito, seria possivel eleger uma câmara formada apenas por membros pertencentes ao partido recentemente alçado ao poder, configurando a lógica do famoso sorites de Nabuco de Araújo e retirando qualquer caráter de representação do novo governo. Nas palavras de Sérgio Buarque de Holanda,

HOLANDA, Sérgio Buarque de. 0 poder pessoal. In: HOLANDA, Sérgio Buarque de (dir.). História Geral da Civilização Brasileira, Tomo II, Vol. 7 Do Império à República. Rio de Janeiro: Bertrand Brasil, 2008, pp. 86-87. A mesma interpretação acerca do funcionamento do sistema político imperial pode ser encontrada, com algumas variantes, em FAORO, Raymundo. Os donos do poder. Rio de Janeiro: Globo, 1987; BARMAN, Roderick J. Brazil. The forging of a nation (17981852). Stanford: Stanford University Press, 1988; e BARMAN, Roderick J. Imperador cidadão. São Paulo: Editora Unesp, 2012.

6

Carlos Carneiro de Campos (1805-1878), 30 visconde de Caravelas, era doutor e professor em Direito, tendo nascido na província da Bahia. Foi deputado por São Paulo em quatro legislaturas, entre 1838 e 1856. Em 1857 foi escolhido em lista triplice para ocupar o cargo de senador, também por São Paulo. No Poder Executivo, foi presidente da província de Minas Gerais em duas oportunidades, em 1842 e entre 1857 e 1860, além de ministro dos Negócios Estrangeiros (1862, 1864 e 1873 a 1875) e da Fazenda (1864 a 1865). Terminou a vida na função de Conselheiro de Estado.

7

CARVALHO, José Murilo de. A construção da ordem: a elite politica imperial. Teatro de sombras: a política imperial. Rio de Janeiro: Civilização Brasileira, 2011, p. 407.
D. Pedro II tinha ciência, evidentemente, de que, em nosso sistema, um Ministério, que para viver dependia da Câmara, fazia a Câmara segundo seu interesse partidário. Sabia também que só dele, Imperador, dependia a dissolução dessas Câmaras, quando entendesse que convinha sustentar um Governo, pois este haveria de ter os meios decisivos para fazer "eleger" os representantes que quisesse e quando o quisesse. Assim surgiam os Gabinetes onipotentes apoiados pelas Câmaras obedientes. Quando as burlas se tornassem clamorosas, então podia usar Sua Majestade da prerrogativa de livremente despedir o Ministério e nomear outro que, por sua vez, iria retomar iguais métodos se não pretendesse desaparecer. (...) Pode-se, pois, dizer que a ação do Imperador vinha a suprir neste ponto o papel dos órgãos mais normalmente autorizados a dar expressão à vontade popular e tinha função semelhante à de um corpo eleitoral, do corpo eleitoral que o Brasil não conhecia. Ou cujas manifestações eram sistematicamente distorcidas para aproveitar a algum agrupamento político. A vontade do povo ficava reduzida em última instância à vontade do Imperador. $^{5}$

Pretendendo inserir-se no debate historiográfico que procura compreender o processo de construção do Estado nacional brasileiro e do funcionamento de suas instituições políticas, este artigo tem por objetivo analisar brevemente dois momentos que indicam a necessidade de questionar este entendimento acerca da tomada de decisões no Brasil império - momentos nos quais emergiu uma relação entre os poderes Legislativo e Executivo que está longe de corroborar a tese segundo a qual ao primeiro caberia apenas referendar as decisões tomadas de antemão e apresentadas pelo segundo; nos quais elementos que sugerem o efetivo funcionamento de um sistema político de tipo representativo aparecem com bastante clareza, nos levando a pelo menos considerar a possibilidade de que, no final das contas, talvez 0 regime imperial brasileiro não tenha tido no parlamento um ator tão secundário como a citação de Sérgio Buarque de Holanda nos faz crer.

Durante os processos decisórios que culminaram na criação da província do Paraná e no estabelecimento da navegação a vapor nos rios amazônicos, a postura adotada pelos deputados gerais certamente não foi de submissão dócil a determinações emanadas de instâncias superiores de poder. É seu posicionamento diante das ações do Poder Executivo com relação a estes dois assuntos, respectivamente nas sessões legislativas de 1843 e de 1853, que configura o objeto de análise das páginas que seguem.

\section{Primeiro momento: os debates sobre a criação da província do Paraná}

Na sessão de 29 de maio de 1843, os debates em torno do projeto de emancipação da comarca de Curitiba na Câmara dos Deputados completavam um mês. Apresentada em 29 de abril por Carlos Carneiro de Campos, baiano que então representava São Paulo e receberia, posteriormente, o título de $3^{\circ}$ visconde de Caravelas ${ }^{6}$, a proposta fora capaz de cindir uma assembleia formada unanimemente por conservadores ${ }^{7}$, colocando os de- 
José Manuel da Fonseca (1803-1871) foi bacharel em Direito nascido na província de São Paulo. Foi representante da mesma na quinta legislatura da Câmara dos Deputados (1843 a 1844) e senador, ainda por São Paulo, entre 1854 e 1871.

9

Anais da Câmara dos Deputados. Sessão de 18 de agosto de 1843, p. 797. Todas as citações dos Anais da Câmara dos Deputados doravante realizadas podem ser encontradas, em versão digital, no site www.camara.leg.br, aba "Publicações e Estudos". Acesso em 28 de maio de 2015.

10

JAVARY, João Alves Loureiro (Barão de). Organizações e programas ministeriais: regime parlamentar no Império. Rio de Janeiro. Arquivo Nacional, 1962, p. 296.

HÖRNER, Erick. Guerra entre pares - a "Revolução Liberal" em São Paulo, 1838-1844. Dissertação de Mestrado. São Paulo. FFLCH-USP, 2005. mais representantes paulistas em rota de colisão direta com qualquer um que se propusesse a defender a medida. Isso envolvia não somente seus colegas parlamentares, mas também o próprio ministério saquarema que, desconfiava-se, estava diretamente empenhado na aprovação da emancipação. Para deputados como José Manuel da Fonseca, nascido em São Paulo e com poderosos interesses econômicos estabelecidos na região de Jundiaí - onde constituiu família e plantou vários hectares de cana, além de inúmeros pés de café ${ }^{8}$ - propor que sua província natal fosse dividida ao meio representava quase um ataque pessoal, uma afronta à integridade de algo que the era muito caro e que merecia sua defesa mais apaixonada. Em suas palavras, tratava-se "do lugar em que nasci, onde está meu umbigo, aquele onde cresci, onde pratiquei os brincos da infância, onde estão todos os meus interesses e, o que é mais, as pessoas que me são mais caras." Não foi portanto por acaso que Fonseca surgiu nos debates como o deputado que mais se empenhou na oposição a tal proposta.

Embora o ano de 1843 seja marcado, em termos parlamentares, pela formação de uma câmara conservadora (eleita em seguida ao decreto de 1 de maio de 1842, que dissolveu a assembleia anteriormente formada sem que esta sequer entrasse em exercício, em virtude dos levantes liberais ocorridos nas províncias de São Paulo e Minas Gerais ${ }^{10}$ ), duas observações podem ser úteis para permitir um melhor entendimento da dinâmica política que caracterizou a ocorrência das discussões que se seguiriam. A primeira, acerca da própria atuação dos deputados recém empossados: se é verdade que todos os eleitos (ou, pelo menos, a esmagadora maioria) pertenciam ou se diziam vinculados ao partido conservador, isto de modo algum implicava, neste momento, em uma atuação unânime ou em uma homogeneidade de vistas com relação às questões mais candentes da agenda política imperial. Um caso exemplar deste fato pode ser observado, precisamente, na atuação da bancada paulista, profundamente dividida pelo projeto de emancipação de sua comarca.

Nominalmente conservadora, a representação parlamentar de São Paulo surgia, nesta sessão da Câmara dos Deputados, como herdeira direta dos embates que culminaram no movimento político iniciado em Sorocaba, no ano anterior. Neste sentido, como um dos membros mais atuantes do chamado partido da ordem daquela província, Carlos Carneiro de Campos era constantemente acusado de ser um forasteiro - epíteto comumente atribuído aos membros daquela agremiação política - razão pela qual atuaria defendendo sempre os interesses da corte, mesmo quando estes estivessem em oposição aos mais legítimos anseios paulistas. José Manuel da Fonseca se valeu largamente desta ideia em seus discursos, nos quais estendia suas criticas ao deputado Joaquim José Pacheco, também defensor da emancipação de Curitiba, membro do mesmo grupo político ao qual pertencia Carneiro de Campos, e principal responsável por seu órgão de imprensa - o jornal A Phenix ${ }^{11}$.

Por seu turno, não foram poucas as oportunidades nas quais os deputados paulistas que se opunham ao projeto em debate foram acusados de provincialismo, ideia que remetia a uma pretensa incapacidade destes políticos em conceber a política em termos mais amplos, afeitos que estavam apenas aos seus interesses mais imediatos e localistas. No âmbito do espectro político de São Paulo, estas críticas eram rotineiramente direcionadas ao chamado partido paulista, que contava entre seus membros com nomes como Nicolau Pereira de Campos Vergueiro, Rafael Tobias de Aguiar e 
Sobre o processo histórico de formação de consolidação deste grupo ver: MATTOS, IImar Rohloff. O tempo saquarema: a formação do Estado imperial. São Paulo. Hucitec, 2004.

14 Para além destes nomes, compunham o gabinete, ainda, os deputados José Antônio da Silva Maia (ministro do Império) e Joaquim Francisco Viana (ministro da Fazenda), além do oficial-general do Exército, Salvador José Maciel (ministro da Guerra), configurando um ministério formado em sua maioria por membros oriundos do Poder Legislativo imperial. JAVARY, Barão de. Op. cit, pp. 89-90.

15

Anais da Câmara dos Deputados. Sessão de 29 de maio de 1843, p. 396.

16

Único dispositivo da Constituição de 1824 voltado exclusivamente para a organização territorial do Império, determinava que: "o seu território é dividido em províncias, na forma em que atualmente se acha, as quais poderão ser subdivididas, como pedir o bem do Estado." Como se vê, tratava-se de um artigo bastante vago, que dava margem para as mais variadas interpretações.
José Antônio Pimenta Bueno, não por acaso alguns dos principais chefes do levante de $1842^{12}$. Ainda que estes políticos não fizessem parte da câmara na sessão em que se desenrolaram os debates aqui brevemente analisados (Vergueiro ocupava, contudo, uma cadeira no Senado, enquanto Tobias de Aguiar e Pimenta Bueno em breve seriam eleitos deputados), não deixa de ser interessante notar que as acusações a eles dirigidas na arena política provincial encontravam eco no parlamento, sendo dirigidos a políticos que pudessem ser identificados com suas posições (ainda que, possivelmente, à revelia), e influenciando poderosamente um debate que, se levarmos em conta apenas a filiação partidária dos deputados nele envolvidos, tinha tudo para ser rapidamente concluído - em termos completamente opostos aos que se verificaram na prática, é bom que se diga.

Para além da composição parlamentar, o ano de 1843 foi marcado, ainda, por um acontecimento de grande alcance também na esfera do Poder Executivo imperial. Trata-se da empossamento, em 23 de janeiro, do terceiro gabinete do Segundo Reinado, o primeiro no qual atuariam conjuntamente alguns dos principais nomes do grupo político que se tornava cada vez mais conhecido como saquarema ${ }^{13}$ : Honório Hermeto Carneiro Leão, futuro marquês do Paraná, então senador que foi nomeado ministro da Justiça e dos Negócios Estrangeiros (sendo posteriormente substituído, em ambas as pastas, por Paulino José Soares de Sousa, futuro visconde do Uruguai, então deputado geral); e Joaquim José Rodrigues Torres, futuro visconde de Itaboraí, também eleito para a câmara e nomeado titular da pasta da Marinha ${ }^{14}$. Grupo que se tornaria célebre por sua capacidade de conduzir políticas de alcance nacional mas que não conseguiria, nesta sua primeira experiência ministerial e no que tange especificamente à emancipação da comarca de Curitiba, fazer com que o projeto fosse aprovado pela maioria de seus colegas deputados.

De fato, a posição ministerial com relação ao projeto de Carneiro de Campos gerou, em um primeiro momento, dúvidas. Para os parlamentares envolvidos nas discussões em torno dessa proposta, confirmar ou refutar a suspeita de que o governo estaria por trás de sua apresentação configurava uma necessidade que urgia fosse satisfeita. Neste sentido, Venâncio Henriques de Rezende, pernambucano que representava, em tal legislatura, a província mineira, fez coro com uma das principais reivindicações de José Manuel da Fonseca: o projeto deveria ser adiado, para que o governo pudesse enviar à câmara mais informações sobre o tema em foco ${ }^{15}$. Na verdade, para ambos os deputados, a questão era mais profunda. Exigir que o governo central enviasse mais informações significava cobrar que se posicionasse sobre a criação da nova província. Tratava-se, nas palavras de Fonseca, de um tema estratégico, sobre o qual não cabia ao Poder Legislativo antecipar-se ao Executivo. Somente este possuía as informações necessárias para saber quais províncias deveriam ser divididas a bem do Estado, como determinava 0 artigo segundo da Constituição de $1824^{16}$. Nestes termos, sem esses dados o parlamento não estava habilitado a debater o assunto, e fazê-lo representaria a quebra indevida da divisão de competências que deveria prevalecer na administração imperial. Se a medida proposta contava com o "empenho" do governo central, como acreditava o representante paulista, deveria ser do interesse deste enviar ao parlamento as informações pedidas e pronunciar-se abertamente sobre a questão, evitando desta forma o seu adiamento.

Embora Carlos Carneiro de Campos e Herculano Ferreira Pena, deputado por Minas Gerais, garantissem que já havia na casa alguns documentos 
17

Anais da Câmara dos Deputados. Sessão de 31 de maio de 1843, p. 448.

18

Idem. Sessão de 29 de maio de 1843, p. 396.

\section{9}

Para mais detalhes sobre este debate e sua relação com o tema aqui analisado, ver: GREGÓRIO, Vitor Marcos. Dividindo as províncias do Império: a emancipação do Amazonas e do Paraná e o sistema representativo na construção do Estado nacional brasileiro (1826-1854). 486f. Tese (doutorado em História Econômica). Faculdade de Filosofia, Letras e Ciências Humanas, Universidade de São Paulo, São Paulo, 2012.

20

Anais da Câmara dos Deputados. Sessão de 1 de junho de 1843, p. 455

21

Idem. Sessão de 14 de junho de 1843, p. acerca do tema, não eram todos os deputados que os consideravam suficientes. Ângelo Muniz da Silva Ferraz, barão de Uruguaiana e representante da Bahia era um destes. Para ele, não era possivel discutir com os dados disponiveis e sem que os deputados soubessem qual era a posição do Poder Executivo acerca desta questão:

(...) na discussão têm aparecido ideias que creio que o governo deve rebater ou confirmar: uma é que o crédito do governo está comprometido na passagem do projeto; a segunda é que, se o projeto não passar, talvez haverá descontentamentos e perigo de que as ideias desorganizadoras de Piratinim [região deflagrada pela Guerra dos Farrapos] achem eco e apoio na comarca de Curitiba. ${ }^{17}$

As cobranças tornavam-se cada vez mais abertas e numerosas. Assim, além do barão de Uruguaiana, de José Manuel da Fonseca e de Venâncio Henriques de Rezende, também Joaquim Manoel Carneiro da Cunha, representante da Paraiba, "lamentou" o silêncio do governo não apenas sobre esta questão, mas igualmente sobre a criação da província do Rio Negro ${ }^{18}$, discussão que corria em paralelo e envolvia a maior comarca em extensão territorial do Grão-Pará19. E João Antunes Correia, deputado por Minas Gerais, preferiu colocar os vínculos partidários acima de suas convicções pessoais, aguardando um posicionamento do ministério saquarema para decidir sobre seu voto:

Sr. Presidente, há muito tempo que a minha convicção é que de divisão, de criações, de subdivisões não tem resultado benefício algum (apoiados), e pela maior parte, em vez de benefício, acarreta-se um chuveiro de males. (...) [mas], se por ventura o nobre ministro da marinha [Joaquim José Rodrigues Torres], que ontem pediu a palavra, apresentar esta medida como profícua à administração, como preservativo do mal, se mostrar que o governo de alguma maneira fica comprometido se o projeto que se discute não passar, eu de muito bom grado prestar-Ihe-ei o meu voto. ${ }^{20}$

0 representante dos mineiros receberia, alguns dias depois, ácida critica de José Manuel da Fonseca, para quem semelhante postura representaria grave risco ao sistema político do país, já que levaria o Poder Legislativo a submeter-se completamente ao Poder Executivo. Nas palavras do deputado paulista,

0 nobre deputado fez toda a oposição ao projeto, filha de sua convicção, e depois declarou que votaria pelo projeto se o governo declarasse que o apoiava. Se se estabelecesse esse princípio do nobre deputado, o governo representativo seria uma perfeita burla... cumpre que o corpo legislativo apresente o seu pensamento, resista ao governo quando entenda que ele vai errado; influa ativamente sobre o governo, e não seja passivo... e sempre passivo. ${ }^{21}$

A postura de Fonseca, neste caso, era de um defensor vigoroso da completa independência dos poderes, única forma eficaz de evitar os abusos e transgressões por parte de qualquer um deles. Ao Poder Legislativo cumpria não apenas vigiar o Executivo, mas também influenciar decisivamente em suas decisões. Para que isso fosse possível, tornava-se necessário que o ministério se posicionasse livremente com relação ao tema em debate. Do 
22

Entre 1838 e 1852, a província de São Paulo esteve dividida em sete comarcas. A primeira tinha sua capital em Taubaté e abarcava, grosso modo, a região do vale do Paraíba (Pindamonhangaba, Guaratinguetá, Areias, Bananal, Silveiras, Lorena, Queluz). A segunda comarca era sediada em São Paulo, e englobava algumas povoações vizinhas à capital da província (Santo Amaro, Atibaia, Bragança, Mogi das Cruzes, Paraibuna, São José, Jacarei). A terceira comarca, com capital em Jundiaí, envolvia povoações que se destacariam pela produção de açúcar, café e alimentos (São Carlos, atual Campinas, e Constituição, atual Piracicaba). A quarta comarca tinha em Itu sua capital, e envolvia mais povoações do interior: Porto Feliz, Capivari, São Roque, Sorocaba, Itapetininga, Itapeva. A quinta comarca, com capital e Curitiba, era constituída pelo território que formou, a partir de 1853, a província do Paraná, com as povoações de Castro, Guaratuba, Vila Nova do Príncipe, Antonina e Paranaguá. A sexta comarca, com capital em Santos, envolvia as povoações do litoral (Cananéia, Iguape, Conceição, Xiririca, São Vicente, São Sebastião, Vila Bela, Ubatuba). Finalmente, a sétima comarca era sediada na vila Franca do Imperador, e envolvia as povoações de Mogi Mirim e Casa Branca. HÖRNER, Erick, op. cit., pp. 5-8; PEREIRA, João Félix. Chorographia do Brazil. Lisboa: Imprensa de Lucas Evangelista, 1854, p. 12. discurso de Fonseca emerge uma crítica feroz a uma prática que a historiografia consideraria, décadas mais tarde, algo corriqueiro nas lides parlamentares. 0 que o deputado paulista fez foi externar sua oposição a algo que considerava uma burla do regime político vigente, algo que deveria ser completamente expurgado das práticas políticas, para o bem do pais. Esta não foi a única oportunidade em que o representante paulista se expressou nestes termos, sendo que não raro é possível vislumbrar a percepção, por parte do taquígrafo que tomava nota dos discursos, de diversos "apoiados" emitidos do plenário.

Longe de manter essa postura apenas no âmbito do discurso, Fonseca se esforçou por sustentar sua oposição à emancipação da quinta comarca paulista ${ }^{22}$ mesmo quando o visconde de Itaboraí, como se verá posteriormente, confirmou que o ministério era amplamente favorável a ela. As cobranças por um posicionamento do governo devem ser interpretadas, assim, não como a busca pelo elemento definidor do voto de toda a assembleia, mas sim como a procura por mais um fator do qual os parlamentares iriam se valer na hora de realizar o cálculo que levaria à definição de sua posição. Agir de modo diferente seria digno de críticas, ao menos para uma parte dos deputados dos quais José Manuel da Fonseca se fez porta-voz. Afinal, representaria a anulação da autonomia legislativa de que os membros da câmara

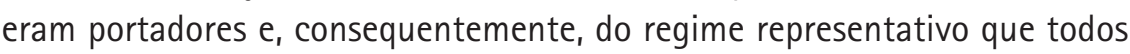
trabalhavam para consolidar.

0 que o representante paulista parece não ter percebido (talvez intencionalmente, pois se tratava aqui de defender sua posição com todas as estratégias possíveis) é que o alinhamento à opinião do gabinete saquarema também era fruto do exercício desta autonomia tão entusiasticamente defendida por ele. 0 importante era que não se configurasse como algo obrigatório, o que certamente não era o caso. 0 ponto, aqui, é que a emancipação de Curitiba, com a consequente perda de território por parte de São Paulo, não era uma questão vital para o mineiro João Antunes Correia. Talvez por isso ele tenha considerado esta uma boa oportunidade para alinhar-se ao governo, possivelmente como uma estratégia para conseguir seu apoio com relação a assuntos que considerasse mais importantes. Para Fonseca, com interesses diretos envolvidos no debate, isso soava como algo completamente inaceitável. Portanto, nem tão generalizado que sua prática pudesse passar completamente despercebida, nem tão reprovável como sugere a intervenção do representante dos paulistas, tratava-se na verdade de algo próprio dos debates políticos, que longe de desqualificá-los conferia-lhes ainda maior complexidade.

Até mesmo Carlos Carneiro de Campos, propositor da emancipação de Curitiba na Câmara dos Deputados e seu principal defensor, cobrou abertamente que o gabinete deixasse claro seu posicionamento adicionando ao debate um elemento que, provavelmente, o levaria a fazê-lo em termos favoráveis ao seu projeto:

Eu quisera que o governo tomasse uma parte muito ativa nesta discussão; julgo que isto era da obrigação do governo (apoiados); porque entendo que, estando a população da comarca da Curitiba persuadida de que o ministério transacto apoiava os seus desejos, confiando a comarca nos princípios da administração, empenhouse o mais possivel, e pode-se dizer quase unanimemente, para que aquela parte do território da província de São Paulo não se ressentisse da comoção que apareceu em 
Anais da Câmara dos Deputados. Sessão de 31 de maio de 1843, p. 435

Correspondência, de João da Silva Machado ao barão de Monte Alegre, presidente da província de São Paulo, em 23 de junho de 1842. In: Divonzir Beloto. A criação da província do Paraná: a emancipação conservadora. Dissertação (mestrado). Pontifícia Universidade Católica, São Paulo, 1990, p. 63.

25

Ofício do barão de Monte Alegre a Cândido José de Araújo Viana, ministro do Império, em 30 de julho de 1842. In: Divonzir BELOTO, Op. cit., p. 65. outros pontos da província. Os habitantes da Curitiba entenderam que podiam esperar da administração a satisfação de seus desejos; julgo mesmo que certas circunstâncias influiram ou puderam autorizar esta confiança; não posso afiançar que o governo abertamente desse lugar a que tivessem esta esperança; mas, por certos fatos, eu penso que a população da Curitiba pode julgar-se autorizada para confiar nos esforços das pessoas que atualmente têm em suas mãos o poder de governar o pais, e daqueles que anteriormente o tiveram. Eu por isso digo que, se o governo entende que esta providência é conveniente, como estou autorizado a crer, o governo deve ser muito explícito a este respeito. (apoiados) ${ }^{23}$

A referência ao levante liberal ocorrido em São Paulo e Minas Gerais um ano antes, em 1842, era direta e tinha como objetivo lembrar a seus colegas parlamentares e ao gabinete conservador do acordo que fora costurado com membros da elite curitibana na ocasião. Encarregado de manter a ordem na comarca em um momento no qual o governo central temia não apenas as consequências da revolta iniciada em Sorocaba mas, também, os desdobramentos da guerra entre farroupilhas e tropas monárquicas ao sul, João da Silva Machado propôs aos liberais da quinta comarca paulista uma troca: estes deveriam abster-se por completo de aderir ou oferecer apoio a qualquer um dos movimentos e, em troca, o presidente de São Paulo, José da Costa Carvalho (barão de Monte Alegre), intercederia pessoalmente junto ao ministério pela criação de uma província na região. Negociação descrita com minúcias em correspondência enviada por Machado a Monte Alegre:

\footnotetext{
Vou contar a V. Ex. com alguma minuciosidade o que se tem passado nesta comarca. A notícia da rebelião em Sorocaba derramou aqui a confusão por haver chegado conjuntamente com a $1^{\text {a }}$ Proclamação, ordem e cartas diversos. Em consequência fizeram-se reuniões noturnas, uns queriam a separação, nomeando um presidente, outros um governo provisório de três membros, outros finalmente não sei o que. Até a câmara se reuniu para dar posse aos empregados policiais. Foi quando felizmente chegaram aquelas cartas que V. Ex. mandou pela marinha com tanta prontidão. Sendo uma para o Tenente Cel. Miguel Marques dos Santos, que ali se achava, publicou seu contexto à face da câmara, e como além da recomendação da ordem, Ihes assegurava a separação da comarca, elevando-se à província, ficaram satisfeitos e desamotinaramse. (... ) Enfim, salvou-se a comarca, que esteve por um fio de insurgir-se, porém agora parece-me que está segura. (...) Tenho empenhado a minha palavra que Curitiba há de ser elevada à província e portanto V. Ex. não me deixe ficar em falta. ${ }^{24}$
}

João da Silva Machado não ficaria em falta, pois em 30 de julho de 1842 o barão de Monte Alegre enviava a Cândido José de Araújo Viana, ministro do Império, um minucioso ofício no qual expunha uma série de razões pelas quais entendia ser conveniente a elevação da comarca de Curitiba à categoria de província ${ }^{25}$. Os liberais curitibanos haviam cumprido sua parte no acordo, chegava a hora de o Poder Executivo imperial cumprir a sua. 0 problema é que, para alcançar este objetivo, teria primeiro de convencer os parlamentares da Câmara dos Deputados a votar a favor de uma medida que recebia cerrada - e possivelmente inesperada - oposição.

Não havia mais como adiar. 0 ministério saquarema era chamado mais uma vez a se pronunciar sobre a emancipação de Curitiba, agora por um de seus correligionários mais destacados na legislatura de 1843 - Carlos Carneiro de Campos. Coube então a Joaquim José Rodrigues Torres, futuro visconde de Itaboraí, subir à tribuna para expressar a opinião do governo central sobre 0 assunto. 
26

Anais da Câmara dos Deputados. Sessão de 1 de junho de 1843, p. 456
Na sessão de 1 de junho de 1843, Joaquim José Rodrigues Torres, então ocupante do cargo de ministro da Marinha, tomou a palavra para expor a opinião do governo central acerca da emancipação de Curitiba. Não sem, antes, procurar desobrigar a si e ao ministério do qual fazia parte de participar de debates parlamentares acerca de projetos que não tivessem sido apresentados por eles. Segundo o ministro, sua obrigação limitava-se ao fornecimento de informações pertinentes aos atos da administração, tão somente. Desta forma, não havia nada que o forçasse a participar dos debates acerca da emancipação de Curitiba ${ }^{26}$. Entretanto, se o ministro da marinha não se sentia obrigado a se posicionar sobre o tema, ele quis fazê-lo, o que pode ser explicado pela influência direta que teve na formulação do projeto apresentado por Carneiro de Campos:

É verdade que o ilustre deputado autor do projeto, antes de apresentá-lo, teve a bondade de consultar-me para saber qual era a minha opinião a respeito dele, e qual seria mesmo a opinião de meus colegas [os demais ministros]. Não tive dúvida em asseverar-Ihe que pela minha parte entendia conveniente o projeto; não tive dúvida mesmo de prometer-Ihe que consultaria a opinião de meus colegas, a qual achei de acordo com a minha. Foi isto o que disse ao ilustre deputado, sem todavia contrair o empenho de fazer com que o projeto fosse considerado obra nossa. ${ }^{27}$

A entrada do futuro visconde de Itaboraí no debate é bastante esclarecedora de alguns pontos da dinâmica parlamentar que raramente podem ser percebidos. Primeiro, demonstra que haviam obrigações a serem cumpridas pelos membros do ministério com relação aos membros do Poder Legislativo, fato raramente referido pelos historiadores que defendem uma completa submissão deste com relação ao Poder Executivo. Segundo o próprio ministro, era obrigação dele e de seus colegas oferecerem aos deputados todas as informações possíveis sobre os atos realizados por sua administração, como uma forma de garantir aos representantes da nação as ferramentas necessárias para que realizassem a fiscalização da administração.

$E_{1}$ em segundo lugar, embora o ministro tenha se declarado desobrigado de intervir nos debates acerca da emancipação de Curitiba, ainda assim ele optou livremente por fazê-lo. Aliás, não só optou por defender o projeto de Carneiro de Campos, como também o incentivou a apresentá-lo à câmara, por entendê-lo conveniente para o país sendo secundado, nesta opinião, pelos seus colegas do gabinete saquarema. 0 ministro da Justiça Honório Hermeto Carneiro Leão chegara, inclusive, a aproveitar uma oportunidade em que ocupava a tribuna para também deixar claro seu apoio à medida proposta:

Na minha opinião penso que a província de São Paulo pode ser dividida em duas, e que a comarca de Curitiba pode ser uma nova província. Julgo que daí não resultará desvantagem nem para o Império, nem para a província de São Paulo. A província de São Paulo, desagregada à comarca de Curitiba, ainda ficará assaz vasta e assaz importante, e poder-se-á manter. A comarca de Curitiba não tem grande população, mas tem vasto território, que exige grandes melhoramentos, exige-se mesmo que 
ali se trate de colonizar os vastos sertões destes lugares até o Paraná, para que não tenhamos para o futuro novas questões de limites por esta parte do Império. Creio que muito lucraria o Império se uma administração local se estabelecesse na comarca de Curitiba. Consequentemente se o projeto tiver de ser discutido na presente sessão, não duvido apoiá-lo. E para ser mais explícito, pessoalmente, e sem poder dizer a opinião dos meus colegas, eu apoiaria mesmo um projeto que dividisse a província de Minas em três, e a do Pará em duas. ${ }^{28}$

Não podia haver dúvidas: o gabinete saquarema era amplamente favorável à emancipação de Curitiba, como dois de seus membros mais expoentes fizeram questão de confirmar. Este fato teria que ser levado em conta no cálculo que cada um dos parlamentares faria antes de definir sua posição com relação à questão. Mas a que era devido esse apoio tão claro ao projeto de Carneiro de Campos? Estaria o governo se dobrando ante as exigências das elites curitibanas, fazendo valer a promessa feita por intermédio do marquês de Monte Alegre, então presidente de São Paulo, para que aquela comarca não se aliasse ao levante liberal de Sorocaba e nem à Farroupilha que se desenrolava no Rio Grande do Sul?

Rodrigues Torres negou que fosse essa a causa. Para ele, era um erro acreditar que houvesse existido qualquer tipo de acordo entre o ministério anterior e os "povos" de Curitiba. Entretanto, expressando sua opinião sobre essa possibilidade, afirmou que mesmo que tal acordo tivesse existido, ele deveria ser tomado como um elemento a ser considerado favoravelmente à aprovação do projeto em discussão, e não o contrário:

Eu não quisera que o governo recebesse condições desta natureza; mas nem me parece provado que tal condição fosse imposta, nem vejo a possibilidade de fazerse com os habitantes de Curitiba semelhante transação, e se a esperança de que semelhante medida [a emancipação] fosse tomada produziu tal resultado, é isso, torno a dizer, uma prova da necessidade de elevar-se a comarca da Curitiba à categoria de província, e não vejo aí coisa indecorosa que seja, nem ao governo, nem à representação nacional. ${ }^{29}$

Cumpre analisar brevemente estas primeiras afirmações do futuro visconde de Itaboraí. De suas palavras depreende-se que havia influência direta do governo central na apresentação do projeto de emancipação de Curitiba. Ao apresentá-lo aos ministros antes do debate na câmara, Carneiro de Campos procurava construir uma base de apoio capaz de garantir sua aprovação. 0 cálculo do representante de São Paulo provavelmente foi baseado na seguinte premissa: com uma maioria amplamente conservadora, seria lógico esperar que um projeto apresentado com a anuência de um gabinete conservador teria grandes possibilidades de receber a maioria dos votos sem maiores problemas. Provavelmente esperava que a maioria da assembleia tivesse a mesma atitude do deputado por Minas Gerais, João Antunes Correia que, colocando seus vínculos partidários acima de suas convicções pessoais, se colocou a favor de uma medida que entendia ser prejudicial ao pais. Quase certamente surpreendeu-se algumas semanas depois, quando mesmo com a intervenção favorável de Rodrigues Torres seu projeto acabou sendo adiado.

Por outro lado, ao desvincular a posição governamental de um possível acordo realizado com a elite curitibana, o futuro visconde de Itaboraí apresentava o gabinete do qual fazia parte como dotado de completa auto- 
nomia decisória. Neste sentido, ele apoiaria a emancipação de Curitiba por realmente acreditar em seus beneficios, e não porque era obrigado a isso pela herança deixada por seus antecessores. Mesmo afirmando que tais negociações em nada desabonavam a medida proposta, ele mesmo parecia não acreditar nisso. Se o acordo existira, vincular o projeto de criação da província a ele poderia dificultar sua aprovação na câmara, pois feria os princípios constitucionais e os trâmites normais do funcionamento do governo representativo. Não cabia ao ministério a competência de criar novas províncias, e sim ao parlamento. Portanto, não podia um gabinete comprometer-se com uma elite local em um acordo neste sentido. 0 ministro, se insistisse na existência desta transação, poderia levar os deputados a se posicionarem contra a criação da província em nome da defesa de suas prerrogativas como representantes da nação. Pode-se levantar a hipótese de que, como já havia o rumor da existência do acordo, o gabinete tenha preferido que o projeto fosse apresentado por um deputado e não por um ministro, para dar a ele coloração inteiramente parlamentar.

Parte da estratégia de Carneiro de Campos deu certo. Os ministros foram unânimes em apontar a conveniência do projeto, mas não o consideraram prioritário a ponto de apresentá-lo pessoalmente à câmara. 0 apoio ministerial estava garantido, e foi este fato que impeliu Rodrigues Torres a assumir sua defesa na tribuna, mesmo não se sentindo obrigado a isso. Este apoio, contudo, não seria forte a ponto de transformar o tema em uma questão prioritária:

Mas dir-se-á, se o governo entende que a medida é conveniente, porque não se apressou a apresentá-la? Senhores, muitas coisas há que o governo entendia necessárias; todavia, para que organize propostas e venha apresentá-las à câmara, convém que estude muito maduramente cada uma dessas propostas, que colha todas as informações necessárias para sustentá-las. (...) Demais, como já disse, há muitos outros objetos que devem ocupar a atenção do governo, que, no curto espaço de pouco mais de quatro meses, ocupado com tantos negócios, gastando grande parte do tempo em assistir às discussões das câmaras, não pode ao mesmo tempo organizar e discutir todos os projetos que julga úteis ou necessários para apresentá-los ao corpo legislativo; deve portanto preferir aqueles que reputa mais urgentes. ${ }^{30}$

0 fato de não transformar a emancipação de Curitiba em questão de gabinete não significou, contudo, que o visconde de Itaboraí deixaria de se esforçar para ver aprovado o projeto cuja apresentação encorajou. Ainda que não empenhasse todo o capital político do ministério a seu favor, ele impôs à imensa maioria de deputados conservadores que compunham a câmara a contingência de, ao se opor a esta medida, opor-se também à opinião explícita de seus líderes.

Para justificar seu apoio à emancipação de Curitiba, Rodrigues Torres se valeu da ideia segundo a qual era necessário garantir uma melhor administração "dos interesses de seus habitantes" através de uma divisão que ofereceria à região um governo próprio autônomo, capaz de gerar e administrar recursos próprios, com funcionários próprios e com máquina administrativa própria. Neste sentido, afirmou:

Em geral, entendo que a divisão das grandes províncias é uma medida governamental; entendo que é um meio de administrar melhor os interesses de seus habitantes; 
Por outro lado, ainda segundo o ministro, não havia como administrar satisfatoriamente uma província de grande extensão territorial, principalmente porque seu presidente, de ordinário, não possuía meios para informar-se de todas as necessidades do território sobre sua jurisdição, de todos os interesses das diversas localidades e não tinha como conhecer as personalidades locais mais adequadas para ocupar os cargos de confiança com os quais podia contar ${ }^{32}$. Os resultados deste estado de coisas, segundo Itaboraí, poderiam ser desastrosos. Em primeiro lugar, porque facilitaria a propagação de movimentos revolucionários, ao passo em que dificultaria a adoção de medidas para sufocá-los ${ }^{33}$. Por outro lado, a existência de províncias com grandes territórios favoreceria a formação de elites locais poderosas e influentes o suficiente para embaraçar a adoção de políticas pelas diversas instâncias do poder:

Ninguém ignora também quanto a grande extensão das províncias facilita às influências pessoais organizar, por assim dizer, unidades provinciais fictícias, que estorvam, que embaraçam, que dificultam a marcha do governo geral, unidades provinciais fictícias que muitas vezes se põem em aberta hostilidade com a grande unidade nacional. ${ }^{34}$

Para combater este mal, a melhor política a adotar seria dividir estas províncias, como uma estratégia para fazer com que estas elites se sentissem parte integrante do sistema político imperial, sentissem que seus interesses estavam contemplados pelo acordo político vigente através do necessário aparato administrativo e político provincial. Com isso, ou sua influência seria neutralizada ou seria utilizada de forma "benéfica", caso o processo de inserção destas elites dentro do governo fosse realizado com o sucesso desejado ${ }^{35}$. Assim, a emancipação da comarca de Curitiba surge como um elemento-chave para a garantia da ordem na região. Nas entrelinhas do seu discurso, Rodrigues Torres advertia os deputados de que a oposição a esta medida significava opor-se a que uma grande porção do território imperial recebesse as ferramentas necessárias para gerir seus interesses mais urgentes evitando, assim, que novos grupos políticos se fortalecessem através da defesa de projetos próprios, nem sempre úteis ao desenvolvimento do país como um todo. Algo que se tornava ainda mais necessário naquela comarca que, por possuir fronteira com paises vizinhos, tinha ainda maior necessidade de ser povoada, colonizada, e de ver suas fortificações renovadas ${ }^{36}$. Neste sentido, o aumento de despesas que resultaria desta medida seria amplamente compensado pelos benefícios que o país receberia com ela:

Ora, se é indubitável que uma administração mais próxima desses lugares pode mais eficazmente promover os melhoramentos materiais dessa porção do território brasileiro, se pode concorrer mais facilmente para aumentar-Ihe a povoação, para colonizá-lo, para evitar todas as contestações a que podem dar lugar esses conflitos que a pouco tive a honra de expor à câmara, é claro que o aumento de despesa que daí resultará não deve de modo algum obstar a uma medida que pode produzir resultados tão importantes para o nosso país. ${ }^{37}$ 
Embora proferida por um dos principais líderes saquaremas, esta estratégia de ação não era unanimidade entre os conservadores que se encontravam na câmara. Ângelo Muniz da Silva Ferraz, por exemplo, concordava que a existência de elites locais poderosas marginais ao governo era um grande obstáculo à administração imperial, mas discordava frontalmente da ideia segundo a qual a divisão de províncias seria o meio mais eficaz para enfraquecê-las:

38

Idem. Sessão de 31 de maio de 1843, p. 449.

Ibidem, p. 450

Temo que esta divisão dará mais preponderância a alguém da Curitiba! Estabelecendose uma administração, criando-se uma assembleia provincial, temo que tudo se sujeite aos ditames dessas influências curitibanas. Mal daquele que nesses pequenos lugares não obedece e se põe á disposição dessas influências; se juiz de direito é, depois de passar por grandes desgostos, lá vai degradado para a Palma ou Pastos Bons; se presidente, em breve acaba ou é demitido. ${ }^{38}$

0 caso ficava ainda mais grave com as notícias - que na câmara se entendiam por rumores - acerca da negociação realizada em 1842. Neste caso, segundo o barão de Uruguaiana, se a emancipação estivesse sendo proposta em atendimento ao que havia sido acertado os riscos para o país se tornavam ainda mais graves, já que a influência destes grupos de Curitiba atingiria um nível de extrema periculosidade. Uma vez atendida a reivindicação de emancipação com relação a São Paulo novas exigências se seguiriam, colocando em grave perigo a organização política e a integridade territorial do Império ${ }^{39}$. Afinal, se mesmo desprovidos de um aparato administrativo os grupos políticos da comarca já eram capazes de fazer com que o governo central se dobrasse às suas determinações, o que não teriam condições de fazer caso a emancipação fosse concedida e eles passassem a ter condições de se fazer representar no parlamento? 0 barão de Uruguaiana demonstrava o temor de que o equilibrio político então existente fosse severamente alterado, o que colocaria o regime monárquico em considerável perigo.

Em sua opinião, portanto, a manutenção da ordem no país viria apenas com o controle atento das elites locais, nunca com sua inclusão em um aparato administrativo provincial que, nas suas palavras, serviria apenas para fortalecê-las. Trata-se de uma discordância importante entre saquaremas eminentes a indicar que ainda existiam, em 1843, disputas importantes no interior desse grupo com relação a quais políticas eram melhores para o país e quais seriam as melhores formas de implementá-las. Nesse sentido, dentro do partido conservador, negociações também se faziam necessárias para que seus membros pudessem definir quais seriam suas estratégias de ação.

Se o barão de Uruguaiana ofereceu uma estratégia alternativa à divisão de províncias para alcançar a manutenção da ordem no Império, Carlos Carneiro de Campos foi, por sua vez, tão - ou mais - explícito que o próprio Rodrigues Torres na defesa de suas ideias. Segundo este deputado, não deveriam ser medidos os esforços necessários para a manutenção da ordem pública do país. Portanto, o projeto que estava em debate não podia ser combatido com base no aumento de despesas que ele representava, pois estas seriam mais que compensadas pelos efeitos que provocariam:

Mas, senhores, quem duvida votar por 8 ou 10 contos de réis nas circunstâncias atuais 
40

Ibidem, p. 436

41

Ibidem, p. 435

42

Idem. Sessão de 18 de agosto de 1843, p. 796

43

Anais do Senado. Sessão de 24 de julho de 1850 , p. 444. Todas as citações dos Anais do Senado doravante realizadas podem ser encontradas, em versão digital, no site www.senado.gov.br, aba "Publicações". Acesso em 29 de maio de 2015. em que tantas coisas influem para complicar nosso estado político? Quem duvidará votar por esta quantia para firmar melhor a ordem pública e tranquilidade do Império? Além dessa desordem do Rio Grande, além da agitação que se tem produzido no país, eu vejo que todos os dias se acumulam elementos de desordem, de agitação, embaraços para o governo, e portanto complicação dos negócios. (...) Eu peço aos nobres deputados que encarem a questão dentro deste ponto de vista, que combatam as minhas razões. Julgo que a arma da razão é a que deve prevalecer entre nós, que aquilo que for mais justo, mais conveniente ao país é que deve ser por nós abraçado; e portanto não devemos considerar a questão debaixo de um ponto de vista mesquinho, pequeno, mas debaixo daquele ponto de vista que nos foi determinado por aqueles que para aqui nos mandaram - em primeiro lugar salvar o Império. ${ }^{40}$

Tratava-se, portanto, de uma medida destinada a salvar o Império, nas palavras de Carneiro de Campos. Pode-se creditar parte desse discurso a um exagero retórico destinado a impressionar os ouvintes, mas o representante de São Paulo também tinha em vista, quando formulou esta expressão, questões bastante concretas. Entre estas estavam as relacionadas à influência que os países vizinhos e a revolta no Rio Grande do Sul poderiam exercer sobre a vida política do pais, a qual deveria ser evitada por todas as formas possiveis:

Eu julgo que em todos aqueles pontos do nosso território que podem ser invadidos já, ou dentro de poucos anos, de ideias ou princípios anarquizadores que dominam nessas repúblicas, nós devemos ir já pondo embaraços. (...) Eu julgo, Sr. presidente, que é tempo, e mais que tempo, de cuidar daquela parte da fronteira do Império; muitos, repito, olhando para a desordem do Rio Grande, julgam que, abafada ela, tudo está conseguido; eu não considero assim; qualquer que seja o êxito da luta entre Oribe e Fructo, o governo que ficar há de procurar influir no Rio Grande e dar que fazer constantemente às autoridades do Império; e porque acontece isto? É porque o Rio Grande é fronteiro, limítrofe desse pais; e pergunto: o território da comarca de Curitiba não é limitrofe com esse país? Não é limítrofe com o Rio Grande? ${ }^{41}$

0 posicionamento explicitado por Joaquim José Rodrigues Torres, em nome do ministério saquarema, e a argumentação de Carneiro de Campos, formulador do projeto, não foram capazes de diminuir a oposição à emancipação de Curitiba. 0 mesmo seria aprovado em primeira discussão na sessão de 3 de junho de 1843, mas na continuação dos debates em segunda discussão acabaria sendo adiado indefinidamente, em atendimento a um requerimento apresentado por João Evangelista de Negreiros Sayão Lobato, futuro visconde de Sabará e então deputado suplente por São Paulo, em 18 de agosto de $1843^{42}$. Na prática o adiamento significou o definitivo abandono da proposta por aquela legislatura, sendo que o assunto só voltaria a ser considerado sete anos depois no Senado, em condições completamente diferentes e como um aditivo do projeto de emancipação da comarca do Alto Amazonas, no Grão Pará43. Uma câmara unanimemente conservadora derrubava, assim, um projeto que contou com importante demonstração de apoio de um dos principais representantes do ministério saquarema. Algo completamente impensável para um parlamento submisso às determinações do Poder Executivo, formado aliás por membros da mesma agremiação partidária. Mas bastante coerente com o modelo de monarquia representativa que estes políticos tantas vezes afirmaram estar empenhados em construir, na qual cálculos individuais eram realizados, o tempo todo, para determinar quais seriam as posições adotadas por cada um dos deputados ao longo dos diversos processos decisórios nos 
44

Anais da Câmara dos Deputados. Sessão de 13 de maio de 1853, p. 189

45

Idem. Sessão de 11 de julho de 1853, p. 152-153.

46

Antiga comarca do Alto Amazonas, pertencente ao Grão Pará, a província do Amazonas foi emancipada pela lei 592, de 5 de setembro de 1850, após longo processo decisório ocorrido no parlamento imperial. GREGÓRIO, Vitor Marcos. Dividindo as províncias do Império: a emancipação do Amazonas e do Paraná e o sistema representativo na construção do Estado nacional brasileiro (1826-1854), Op. cit.

47

MEDEIROS, Fernando Sabóia de. A liberdade de navegação do Amazonas (relação entre o Império e os Estados Unidos da América). São Paulo: Companhia Editora Nacional, 1938. GREGÓRIO, Vitor Marcos. Uma face de Jano: a navegação do rio Amazonas e a formação do Estado brasileiro (18381867). São Paulo: Annablume, 2012.

48

CARVALHO, José Murilo de. A construção da ordem: a elite politica imperial. Teatro de sombras: a política imperial, op. cit., p. 407.. quais eram chamados a intervir diretamente.

Segundo momento: os debates sobre a navegação do rio Amazonas

Em $1^{\circ}$ de agosto de 1853 iniciavam-se, na câmara dos deputados, os debates em torno do decreto 1037, promulgado pelo governo central em 30 de agosto de 1852 e enviado para aprovação parlamentar em 13 de maio de $1853^{44}$. Este documento concluía uma complexa negociação, levada a efeito pelos ministros imperiais e por Irineu Evangelista de Souza, em torno da introdução de linhas regulares de barcos movidos a vapor no rio Amazonas e alguns afluentes, mediante a concessão de incentivos oficiais. Estes incluíam o pagamento de uma subvenção pecuniária à companhia a ser fundada com esta finalidade pelo futuro barão de Mauá e um privilégio de exclusividade, válido por trinta anos, para que esta pudesse introduzir com vantagem a navegação nos rios amazônicos. Além disso, o governo garantia também a cessão dos terrenos necessários para a fundação de sessenta colônias nas margens do rio Amazonas, a serem planejadas pela companhia e habitadas por índios ou imigrantes estrangeiros, além de um terreno grande o suficiente para que fosse construído um dique particular na cidade de Belém, capital da província paraense.

Em troca destas concessões, Irineu Evangelista de Souza se comprometia a manter em atividade linhas regulares de vapores no rio Amazonas, a fundar uma companhia que nunca poderia operar com um capital inferior a mil e duzentos contos de réis, e a fundar e manter as colônias de indígenas e imigrantes, tão logo recebesse para isso a necessária aprovação por parte do Poder Legislativo ${ }^{45}$. Sob estas bases, a Companhia de Navegação e Comércio do Amazonas seria rapidamente fundada, ainda em 1852, e já no primeiro dia do ano de 1853 inauguraria a linha de navegação a vapor ligando Belém, capital do Grão Pará, à Barra do Rio Negro, capital da recém emancipada província do Amazonas ${ }^{46}$. Culminavam deste modo os esforços do governo central para repelir as pressões internacionais pela abertura do maior rio das Américas à navegação internacional, liderada pelos Estados Unidos e fortalecida a partir de 1850, e para atender às repetidas reivindicações de grupos políticos e econômicos eminentes da região amazônica pela apresentação de uma solução que facilitasse o escoamento das mercadorias produzidas na região favorecendo, deste modo, seu desenvolvimento ${ }^{47}$.

Deste modo, quando o texto do contrato - já tornado decreto - foi enviado para apreciação dos deputados gerais em maio de 1853, os barcos de Irineu Evangelista de Souza já sulcavam as águas do rio Amazonas em viagens regulares $e_{\text {, }}$ provavelmente, não era seriamente considerada a possibilidade de o mesmo ser contestado. Afinal de contas viviam-se os tempos de uma câmara dos deputados conservadora, como conservador era 0 ministério nomeado em 11 de maio de 1852, sob liderança de Joaquim José Rodrigues Torres - o mesmo saquarema que, dez anos antes, havia subido à tribuna para defender a emancipação da comarca de Curitiba ${ }^{48}$.

Talvez este fato ajude a explicar a realização de investimentos consideráveis, por parte do futuro barão de Mauá, para iniciar uma atividade econômica ainda não aprovada pelo parlamento imperial. Politicamente alinhados ao gabinete, é possivel inferir que não se esperava dos deputados gerais mais do que uma postura dócil com relação a um contrato assinado por ministros de sua mesma agremiação política. Mas ainda que a comissão de comércio, indústria e artes formada pelos deputados Viriato Bandeira Duarte (Mato Grosso), Augusto Frederico de Oliveira (Pernambuco) e Frederico 
Parecer emitido pela comissão em 9 de julho de 1853, mas apresentado ao plenário apenas dois dias depois. Anais da Câmara dos Deputados. Sessão de 11 de julho de 1853, pp. 152-153.

50

ESTEFANES, Bruno Fabris. Conciliar o Império. 0 marquês do Paraná e a política imperial, 1842-1856. São Paulo. Annablume. 2014. SANTA CRUZ, Fábio Santiago. Em busca da conciliação: ideias políticas no parlamento do império do Brasil (1831-1855). Tese de Doutorado. Brasília. Universidade de Brasília, 2008.

51

No ministério formado por Joaquim José Rodrigues Torres e empossado em 11 de maio de 1852, ocuparam a pasta da Justiça os deputados José Ildefonso de Sousa Ramos (visconde de Jaguari), e Luis Antônio Barbosa; a pasta da Marinha o deputado Zacarias de Góis e Vasconcelos; a pasta do Império o senador Francisco Gonçalves Martins; a pasta dos Negócios Estrangeiros o senador Paulino José Soares de Sousa (visconde do Uruguai); a pasta da Guerra o senador Manuel Felizardo de Sousa e Melo; e a pasta da Fazenda o mesmo visconde de Itaborai que exercia a função de presidente do Conselho de Ministros. JAVARY, Barão de. Op.cit., pp. 111-112

\section{2}

Dos políticos que ocuparam postos no chamado ministério da conciliação de Honório Hermeto Carneiro Leão, eram deputados quando de sua posse José Tomás Nabuco de Araújo, José Maria da Silva Paranhos (futuro visconde do Rio Branco) e João Maurício Wanderley (barão de Cotegipe). Já Antônio Paulino Limpo de Abreu (futuro visconde de Abaeté) e Luis Alves de Lima e Silva (futuro duque de Caxias) participaram do gabinete enquanto eram senadores do Império. JAVARY, Barão de. op. cit., pp. 113-114.

53

Decreto 523, de 20 de julho de 1847. Presente no site: http://www2.camara.leg.br/legin/fed/ decret/1824-1899/decreto-523-20-julho-1847560333-publicacaooriginal-83096-pe.html. Consulta em 12 de março de 2016

54

BARBOSA, Silvana Mota. O Conselho de Ministros no Império do Brasil. Revista de História, Juiz de Fora, vol. 13, n. 1, p. 52-62, 2007.

55

Anais da Câmara dos Deputados. Sessão de 1 de agosto de 1853, p. 7. de Almeida e Albuquerque (Paraiba) tenha apresentado parecer favorável ao contrato na sessão de 11 de julho de $1853^{49}$, o que se assistiu nas ocasiões seguintes em que o documento esteve na pauta de discussões foi uma série de ataques diretos a alguns de seus dispositivos mais importantes.

Assim como ocorrera em 1843 com os debates em torno da criação da província do Paraná, também estas discussões em torno do estabelecimento da navegação a vapor no rio Amazonas se deram sob condições especiais no parlamento imperial. Vivia-se, então, um período de importantes alterações no panorama político do país as quais culminariam, em apenas algumas semanas, com a formação de um novo gabinete ministerial sob chefia de Honório Hermeto Carneiro Leão, o marquês do Paraná, e o início do chamado movimento da conciliação $0^{50}$. Tais transformações atingiam em cheio a deputados e senadores, já ocupados na tessitura dos novos acordos e alianças que possibilitariam a implantação da nova diretriz política. Como consequência, ao gabinete formado em 1852 apenas com políticos recrutados nas duas casas parlamentares ${ }^{51}$, seguir-se-ia, em 6 de setembro de 1853, outro não menos marcado pela presença de deputados e senadores ${ }^{52}$.

Ao contrário do que acontecera em 1843, contudo, ambos os gabinetes não foram nomeados diretamente pelo imperador. Ao criar o cargo de Presidente do Conselho de Ministros, tendo em vista "dar ao Ministério uma organização mais adaptada às condições do Sistema Representativo" ${ }^{53}, 0$ decreto 523, de 20 de julho de 1847, imprimira uma mudança substancial na administração do Estado imperial. Segundo a Constituição de 1824 em seu artigo 101, que regulava o exercício do Poder Moderador, inciso $6^{\circ}$, caberia ao imperador nomear e demitir "livremente os ministros de Estado". A partir da publicação do decreto, contudo, tal responsabilidade política recairia sobre o Presidente do Conselho de Ministros, restando ao imperador a tarefa de dar sua anuência à escolha realizada. Isso representaria uma alteração importante no espaço de ação do Poder Executivo, uma vez que agora caberia ao presidente realizar as negociações e tecer as alianças necessárias para possibilitar a atuação do gabinete, não apenas no que se referia à sua esfera de atuação mais imediata mas, também, no que tocava às suas atribuições diretas (como a nomeação dos presidentes de província, por exemplo) ${ }^{54}$. Neste sentido, a maciça presença de parlamentares no ministério poderia indicar uma atuação política mais afinada entre as instâncias Executiva e Legislativa do poder imperial, tornando mais simples a aprovação e implementação de medidas importantes para o país - principalmente se atentarmos para o fato de que tanto uma quanto a outra contavam com maioria de membros conservadores. Entretanto, mais uma vez não foi isso que aconteceu, e as criticas dirigidas aos membros do gabinete por seus colegas deputados gerais novamente nos oferece subsídios importantes para compreender a lógica de funcionamento do sistema político imperial de meados do século XIX.

Quando Cândido Mendes de Almeida, deputado pelo Maranhão, subiu á tribuna para se posicionar contra o parecer da comissão de comércio, indústria e artes e iniciar as discussões acerca do contrato, a navegação a vapor do rio Amazonas já era uma realidade há mais de seis meses. Este fato não o impediu, contudo, de ser pouco receptivo ao parecer emitido pela comissão de comércio, indústria e artes. Inicialmente, afirmou não ser contra o contrato em si, mas tão somente favorável a maiores esclarecimentos quanto ao seu conteúdo. Entretanto, o atacou logo em seguida defendendo que "acima das considerações que merece o governo, dos interesses desse empresário, há o interesse do país que deve ser consultado em primeiro 
lugar" ${ }^{\prime 55}$. 0 decreto contrariava frontalmente, em sua opinião, a lei 586 , de 6 de setembro de 1850, apresentada pelo ministério como base de sustentação de sua negociação com o futuro barão de Mauá, pois esta autorizaria o Executivo "a subvencionar companhias com o fim de navegar o Amazonas por meio de barcos a vapor, a promover o seu comércio", mas não a ceder a exclusividade dessa navegação a apenas uma companhia ${ }^{56}$. Isso configuraria, portanto, uma invasão de jurisdição por parte do governo imperial, que teria extrapolado a autorização recebida através da lei 586 ao tomar para si uma atribuição exclusiva do parlamento concedendo, à companhia de navegação do Amazonas, o privilégio de monopólio.

A discussão em torno desta lei daria a tônica dos embates entre os defensores e os opositores do governo imperial na concessão do privilégio de exclusividade a Irineu Evangelista de Souza. Em defesa do gabinete e, ao mesmo tempo, do voto da comissão da qual fazia parte, Viriato Bandeira Duarte sustentou, em seu discurso de 2 de agosto, que a lei 586 dava, sim, ao governo a habilitação "para consignar prestações a quem se propusesse a manter a dita navegação [do rio Amazonas]" ${ }^{17}$. Para além disso, completou o deputado:

Vê-se pois que esse privilégio exclusivo foi concedido por um decreto do governo, e que a comissão nada mais tinha a fazer senão tocar naqueles outros pontos, que precisavam da aprovação desta augusta câmara.

Esses pontos eram: o favor feito a essa companhia da isenção de direitos de meia sisa na compra e venda de suas embarcações; a concessão de certos terrenos nas margens do Amazonas; e a de outro terreno no porto do Pará para o estabelecimento de um dique. A comissão de comércio, indústria e artes apresentou o seu projeto aprovando simplesmente essas concessões já feitas pelo governo, e que para seu complemento precisavam da aprovação dessa augusta câmara.

\section{SR. MENDES DE ALMEIDA: E o privilégio exclusivo?}

SR. VIRIATO: A comissão não tratou disso no projeto, e nem deveria tratar. ${ }^{58}$

Este argumento cristalizou duas posições discordantes no entendimento da relação existente entre os poderes Executivo e Legislativo em meados do século XIX. De um lado, havia a ideia segundo a qual a última palavra sobre a concessão de vantagens para que particulares introduzissem a navegação a vapor nas águas amazônicas cabia ao Legislativo, que delegou ao Executivo a tarefa mediante a lei 586, mas com a ressalva de que este só poderia atuar nos estritos limites desta delegação, como defendera Mendes de Almeida. Por outro lado, surgia a interpretação apresentada por Bandeira Duarte, segundo a qual o Legislativo, com relação àquela matéria, não tinha autonomia suficiente para contestar uma ação do Executivo, cabendo portanto aos deputados apenas tomar ciência das decisões do governo e agir da melhor forma possivel no sentido de viabilizá-las nas partes que dependiam de aprovação da assembleia. Mesmo com esta questão ainda pendente, 0 contrato celebrado entre o governo imperial e Irineu Evangelista de Souza foi aprovado, em primeira discussão, ainda no dia 2 de agosto, iniciando-se a segunda discussão nove dias depois ${ }^{59}$.

A partir de então, a estratégia adotada pelos deputados contrários à 
61

Idem. Sessão de 11 de agosto de 1853, p. 168.

61

Idem. Sessão de 2 de agosto de 1853, p. 27.

62

Ibidem, p. 168.

63

Ibidem, pp. 169-170 aprovação do documento baseou-se na tentativa de forçar a ida ao plenário do ministro do Império, Francisco Gonçalves Martins, para responder aos questionamentos acerca do decreto promulgado e executado sem o prévio conhecimento do Poder Legislativo. É exatamente neste sentido que o deputado pela província da Bahia, Ângelo Muniz da Silva Ferraz (posteriormente Barão de Uruguaiana, deputado que também participara dos debates sobre a emancipação da comarca de Curitiba, em 1843), apresentou logo no início dos discursos do dia 11 um requerimento para adiamento das discussões, sob a alegação de que o mesmo continha algumas ideias que necessitavam de maior esclarecimento como, por exemplo, 0 alcance geográfico do privilégio de exclusividade concedido ${ }^{60}$.

Foi esta a senha para que um novo debate ocorresse nesta sessão: adiar-se ou não os debates até que o ministro do Império comparecesse à câmara para prestar os esclarecimentos pedidos. Viriato Bandeira Duarte estava convencido de que a presença do ministro não era necessária, assim como tampouco era necessário o adiamento da discussão. Em sua opinião, não havia razão para dúvidas quanto ao alcance do privilégio concedido à companhia de navegação. De fato, a comissão de comércio, indústria e artes teria se valido das palavras da lei e do contrato celebrado entre o governo e Irineu Evangelista de Souza para emitir seu voto e elaborar o projeto que ora se discutia, bastando portanto para entendê-lo ler com atenção seus dispositivos:

\footnotetext{
Se a presença aqui do nobre ministro do Império é para se saber qual a extensão do privilégio e dos favores concedidos, julgo-a desnecessária, por isso que o honrado deputado lendo a lei do contrato verá que o privilégio foi concedido para a navegação do Amazonas e colonização de seus afluentes, com os favores que se acham no projeto, tendo o empresário como principal ônus a obrigação de promover a criação de 60 colônias, o que realmente não é pequena obra para quem a quiser executar devidamente. ${ }^{61}$
}

De acordo com o deputado, não apenas estes favores estavam claramente previstos no contrato entre o governo e o futuro barão de Mauá, como este empresário já teria procedido à fundação de sua companhia contando com eles, a qual inclusive já estaria cumprindo com as obrigações que se esperavam dela e que estavam, também, determinadas no documento que ora se discutia. Tratar-se-ia, assim, de uma oportunidade única que não poderia ser desperdiçada, sob pena de o país deixar "de ter por muitos anos no futuro a navegação a vapor naquele rio"62, deixando-o à mercê das pressões de nações muito mais poderosas que requisitavam insistentemente a abertura do Amazonas à navegação internacional. Nestes termos, adiar a discussão neste momento, deixando no ar a possibilidade de não aprovação do contrato regulado pelo decreto 1037, significaria colocar em risco a atividade da Companhia de Navegação e Comércio do Amazonas, já em funcionamento.

Se esta possibilidade efetivamente existia ela não parecia tão ameaçadora para os demais deputados gerais, inclusive para os que representavam as províncias amazônicas. João Wilkens de Mattos, eleito pelo Amazonas, e Fausto Augusto de Aguiar, deputado pelo Grão Pará, não pareceram convencidos pelos argumentos de Bandeira Duarte e defenderam o adiamento dos trabalhos para que o ministro do Império fosse chamado a comparecer 
65

Idem. Sessão de 18 de agosto de 1853, p. 235 na câmara ${ }^{63}$. Não foram os únicos. Colocado em votação, o requerimento de Ângelo Muniz da Silva Ferraz foi rapidamente aprovado, e os debates em torno do contrato foram temporariamente suspensos ${ }^{64}$. Ao ministro Francisco Gonçalves Martins não restava outra alternativa: teria que ir à câmara caso quisesse ver o decreto 1037 aprovado evitando, deste modo, a paralização das linhas de vapores do rio Amazonas. Uma vez mais a postura do parlamento diante do Poder Executivo não foi de submissão, mas sim de atuação autônoma, valendo-se das prerrogativas previstas pelo sistema político monárquico representativo - qual seja a possibilidade de convocar ministros para prestar esclarecimentos tidos como importantes para o bom andamento dos debates na casa.

A sessão do dia 18 de agosto foi a escolhida pelo ministro do Império para comparecer na câmara. Não seria uma jornada fácil para o representante do gabinete. Já nos primeiros discursos acerca do contrato de navegação do rio Amazonas a questão da relação entre os poderes Executivo e Legislativo veio à tona, e Ângelo Muniz da Silva Ferraz foi incisivo em suas colocações:

\footnotetext{
São estas as considerações que eu tenho a fazer: temo muito dos privilégios exclusivos, e pedirei ao Sr. Ministro também que me informe se entende que a concessão desse privilégio exclusivo não depende da aprovação do corpo Legislativo; porquanto, no ofício de remessa desse contrato unicamente $\mathrm{S}$. Ex. se refere neste ponto a um dos dois artigos do mesmo contrato, e não a respeito do privilégio exclusivo. Eu tenho uma opinião muito segura a este respeito, e é que o governo não pode conceder privilégios exclusivos sem autorização ou dependência de aprovação do corpo Legislativo. Neste ponto o corpo Legislativo não concedeu autorização, concedeu auxilio pecuniário, parece que a lei quis excluir a ideia do privilégio; e se depende de aprovação nossa esse privilégio, eu pediria ao Sr. Ministro que considerasse bem se haverá boas razões para ele se conservar. ${ }^{65}$
}

Mais do que um questionamento, o representante da Bahia apresentava ao ministro Francisco Gonçalves Martins uma cobrança: o governo não estava habilitado a conceder privilégios de exclusividade sem consultar, antes, o parlamento. E neste tema em específico a autorização não estava dada, uma vez que a lei 586 teria sido redigida com a intenção bem definida de excluir os monopólios da lista de incentivos que o governo central poderia oferecer a quem se propusesse a iniciar a navegação a vapor dos rios amazônicos. Neste sentido o privilégio deveria ser retirado, a menos que o ministro apresentasse "boas razões" para o manter.

0 ministro buscou apresentá-las. Em seu primeiro discurso teve como objetivo defender o gabinete da acusação de ter concedido o exclusivismo da navegação sem consulta ao poder Legislativo, explicando tal ato pelo caráter urgente da questão da navegação amazônica - como visto acima, um problema que alcançava dimensões internacionais. Além disso, Gonçalves Martins argumentou que em diversas ocasiões no passado medidas que dependiam da aprovação da câmara foram adotadas à sua revelia, sem que por isso os deputados se levantassem em protesto ${ }^{66}$. Procurou justificar, desta forma, 0 ato do governo com a urgência da necessidade de navegação do rio Amazonas e com práticas semelhantes adotadas no passado. 0 ministro do Império não apenas admitia a invasão da jurisdição parlamentar por parte do governo imperial - ainda que buscando justificá-la, como argumentou com o uso efetivo desta prática em outras oportunidades. Caso tenha sido 
67

Ibidem, p. 242

68

Martim Francisco Ribeiro de Andrada (18251886) era filho do conselheiro homônimo e irmão de José Bonifácio, "o moço". Nascido na França, representou São Paulo na legislatura de 1853 a 1856 e, posteriormente, entre 1861 e 1868. Assumiu as pastas dos Negócios Estrangeiros (1866) e da Justiça (1866-1868) no gabinete liderado por Zacarias de Góis e Vasconcelos, sendo, mais tarde, nomeado conselheiro de Estado.
69

Anais da Câmara dos Deputados. Sessão de 19 de agosto de 1853 , p. 260 seu objetivo oferecer aos deputados gerais a oportunidade de subir o tom de suas críticas à concessão do privilégio de exclusividade a Irineu Evangelista de Souza, Francisco Gonçalves Martins não tinha como ser mais bem sucedido.

Na sequência de sua fala assumiu a tribuna José Duarte Lisboa Serra, deputado pelo Maranhão, que imprimiu em seu discurso um tom de reprovação que não pode passar despercebido:

\begin{abstract}
Não me pode satisfazer completamente a explicação dada pelo nobre ministro, quando, para defender-se, disse que fez o que sempre se tem em casos idênticos praticado, porque não considero semelhante prática, sendo abusiva como me inclino a crer, suficiente para justificar novos atos da mesma natureza. Se tal princípio pudesse prevalecer, se cada governo devesse em tudo imitar o seu antecessor, a responsabilidade dos ministros seria uma quimera e os abusos se perpetuariam; poderíamos mesmo chegar ao absurdo de censurar um ministro que, desobedecendo à lei da imitação, quisesse dar fiel execução às leis do país; poderíamos chegar ao absurdo ainda mais monstruoso de alegar em sua defesa o ministro que fosse acusado por abuso de poder, que 'a prática anterior era toda igualmente abusiva, e não devia o governo, por um ato regular e conforme às leis, ir perturbar a harmonia, a homogeneidade desse belo quadro de irregularidades. 67
\end{abstract}

Os discursos seguintes foram assumindo, em um crescendo, um tom de revolta que culminou nos ataques desferidos por Martim Francisco Ribeiro de Andrada, deputado por São Paulo, na sessão do dia 19 de agosto ${ }^{68}$. Sua fala pode ser sintetizada no trecho abaixo, longo, mas plenamente justificado por seu conteúdo:

(...) o censuro porque ele concedeu um privilégio que não estava na letra da lei; censuro-o quando alienou bens nacionais, e concedeu terras devolutas pertencentes à nação sem autorização do corpo Legislativo; e censuro-o ainda quando no decreto que precede o contrato se declara que ele voltará ao corpo Legislativo unicamente para que este o aprove somente na parte relativa à dispensa de imposições. 0 que é de uma estranhável prepotência e revela o desprezo da lei.

(..)

Do simples fato, senhores, de estabelecer o governo o privilégio em favor da companhia, não se deve deduzir que já existem direitos adquiridos, porque nenhum privilégio pode ser concedido pelo governo, pois isso é da atribuição do corpo Legislativo.

\section{(..)}

Suponho que, quando se trata de uma disposição legislativa como essa, que implica a concessão de direitos não consignados na legislação vigente, só quem é competente pra alterar o que há a tal respeito é o poder Legislativo, e nunca o Executivo, o qual quando muito poderá ter a iniciativa da proposta, que nunca deverá ser considerada com força de lei. ${ }^{69}$

Embora liberal, Martim Francisco Ribeiro de Andrada exemplificou, com sua fala, os ânimos de grande parte do plenário - o qual contava com confortável maioria de conservadores. É bem verdade que o decreto 1037 estava sendo discutido apenas algumas semanas antes da queda do gabinete 
70

Ibidem, p. 253

71

Loc. Cit.
Anais do Senado. Sessão de 24 de agosto de 1853, p. 89 . de Joaquim José Rodrigues Torres e da formação do chamado ministério da conciliação de Honório Hermeto Carneiro Leão. Mas ainda assim chama a atenção o nivel das críticas ao gabinete liderado por um dos membros da eminente trindade saquarema, em um momento no qual seria de esperar que ele contasse com a simpatia de uma câmara formada amplamente por copartidários. E que essas críticas tenham sido concentradas exatamente no tema da relação entre os poderes Executivo e Legislativo do Império, girando em torno da acusação de invasão, por parte do primeiro, da jurisdição exclusiva do segundo.

Ainda na sessão de 19 de agosto duas emendas foram apresentadas ao plenário, ambas redigidas com o objetivo de alterar o contrato celebrado entre o governo e Irineu Evangelista de Souza no tocante à concessão do privilégio de exclusividade. Pela emenda apresentada por Joaquim José Pacheco, representante da província de São Paulo, o contrato era aprovado com exceção do privilégio de exclusividade, ficando entretanto o governo autorizado a elevar a subvenção concedida à companhia de navegação fundada pelo futuro barão de Mauá ${ }^{70}$. Acabou sendo rejeitada em votação. Entretanto, a emenda apresentada por Ângelo Muniz da Silva Ferraz seria aprovada, com a determinação de que o governo deveria resgatar, mediante pagamento de indenização à companhia, o privilégio de exclusividade do modo que julgasse mais conveniente ${ }^{71}$.

Os ásperos debates terminavam, na câmara, em tom de certa forma conciliatório. Resolvido o impasse criado pela ação interpretada como excessivamente centralizadora do Poder Executivo o contrato poderia continuar a ter vigência, garantindo assim que a navegação a vapor do rio Amazonas, já iniciada, não seria interrompida. Esta aprovação, contudo, não representou o fim dos ataques ao gabinete imperial. Restava ainda passar o decreto 1037 pelo crivo do Senado, aonde o tom dos discursos não seria muito diferente do verificado entre os deputados.

Nesta nova instância legislativa as discussões se iniciaram na sessão do dia 24 de agosto, menos de uma semana após a conclusão dos debates na câmara. Entre os senadores os termos do contrato modificado pelos deputados foram bem aceitos, principalmente o fato de que a concessão do privilégio de exclusividade já havia sido rejeitado e, portanto, não constava mais do texto em discussão. Os senadores poderiam, em todo caso, trazer à tona o assunto novamente e devolver o privilégio ao projeto, provocando uma sessão conjunta das duas casas para resolver definitivamente a questão. 0 fato de terem optado por não fazê-lo, somado aos discursos proferidos na câmara vitalícia, permitem vislumbrar com clareza que não era essa a intenção predominante. Apenas um senador, Honório Hermeto Carneiro Leão - que seria convidado para formar um novo ministério apenas alguns dias mais tarde - pronunciou-se a favor do privilégio de exclusividade. Em sua opinião a concessão do privilégio por trinta anos não era um mal, pois não ofenderia nem os interesses públicos nem os interesses particulares do país. Desta forma, a emenda apresentada pelos deputados no sentido de retirá-la do contrato não era necessária nem vantajosa, mas ele votaria pelo contrato alterado mesmo assim, como um esforço pessoal para agilizar o processo de aprovação ${ }^{72}$.

A fala do marquês do Paraná chama a atenção pelo sentimento demonstrado pelo experiente político no trato do contrato assinado entre 0 governo imperial e Irineu Evangelista de Souza: urgência. Ele prometeu se abster de entrar em maiores considerações acerca de pontos específicos do 
73

lbidem, p. 88

74

Loc. Cit.

75

Ibidem, p. 89. documento, abster-se mesmo de talvez confrontar diretamente uma emenda que reputava inconveniente, em nome de uma mais rápida aprovação. Uma vez fundada a Companhia de Navegação e Comércio do Amazonas e uma vez iniciadas as suas atividades, melhor seria que o contrato fosse aprovado o mais rapidamente possivel, ainda que ao preço de não o ser nos termos originalmente negociados.

Provavelmente o marquês não era o único a carregar consigo este sentimento de urgência com relação à aprovação do decreto 1037 pelos senadores. É possivel inferir que também os membros do gabinete conservador compartilhavam dele. Uma indicação bastante forte neste sentido é dada pelo fato de que o ministro do Império, Francisco Gonçalves Martins, desta vez resolveu se antecipar a uma provável convocação para prestar esclarecimentos ao plenário ao se oferecer voluntariamente para fazê-lo, comparecendo à sessão que marcou a entrada do tema na pauta de discussões. Atitude sem dúvida compreensível, principalmente após a experiência vivida na câmara dos deputados, mas que deu ensejo a que os senadores também questionassem duramente o governo acerca da concessão de um privilégio de exclusividade sem prévia autorização do Poder Legislativo. Manoel de Assis Mascarenhas, senador pelo Rio Grande do Norte, tomou a si a tarefa de demonstrar todo o descontentamento com tal postura do governo central. Apresentando-se como um grande defensor da livre concorrência, já em seu primeiro discurso dom Manoel lançou ao ministro a pergunta que considerava crucial: em que lei o governo havia se baseado para conceder

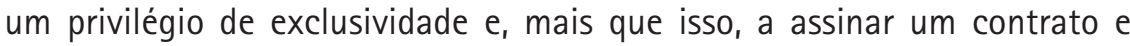
colocá-lo em execução sem prévia autorização do parlamento imperial? Em sua opinião não havia lei alguma que autorizasse o ministério a isso, dai seu estranhamento com relação ao fato ${ }^{73}$.

A resposta do ministro veio nos mesmos termos da que já havia sido apresentada aos deputados gerais. Em sua opinião seria até possivel contestar ao governo, com argumentos bastante plausíveis, o direito de conceder privilégios sem consulta prévia ao poder Legislativo. Mas o fato é que 0 governo já havia lançado mão deste expediente mais de uma vez anteriormente, sem que o parlamento tivesse se manifestado a respeito do assunto ${ }^{74}$. Mais uma vez Gonçalves Martins reconhecia que a relação entre os poderes Executivo e Legislativo era marcada por invasões constantes de jurisdição por parte do primeiro, sem que o segundo se mostrasse incomodado com isto na maior parte das vezes. Além disto, em sua opinião a autorização dada ao Poder Executivo nos termos da lei 586, de setembro de 1850, para introduzir a navegação a vapor no rio Amazonas era tão ampla, que o governo não podia deixar de sentir-se habilitado para realizá-la utilizando-se de todos os meios necessários. Até porque se os ministros tivessem ficado na estrita dependência de aprovação de deputados e senadores para iniciar a navegação do rio, ela ainda não seria uma realidade e a região não teria recebido os favores que esta atividade econômica trouxe consigo ${ }^{75}$.

Mesmo questionamento, mesma resposta. Mas se na câmara a argumentação do ministro Gonçalves Martins levou a críticas que apenas paulatinamente foram se tornando mais ácidas, no senado a resposta foi uma explosão de indignação por parte do senador Manoel de Assis Mascarenhas:

O Sr. Ministro do Império é o maior violador de leis que tem havido, porque conhece a terra em que está, e sabe que assim caminha para o capitólio; mas muito perto 
deste fica a rocha Tarpéa... É impossivel que a Providência não mande um castigo horroroso sobre o Brasil por causa do procedimento deste governo... demônio... mas o Sr. Presidente não gosta que se use deste termo. ${ }^{76}$

0 adjetivo de "demônio", quando atribuído ao governo por um senador do império, não pode passar despercebido. É difícil conceber que um parlamento submisso possa gerar tal arroubo de retórica vindo exatamente do Senado, concebido para ser um contraponto de moderação frente ao radicalismo da câmara dos deputados, principalmente quando se percebe que, ao final dos debates, ele teve suas principais reivindicações plenamente atendidas pelo Poder Executivo. Mas se, para dom Manoel, o pais estava sendo dirigido por um governo demoníaco e colocava-se sob o risco de um castigo divino por conta disto, o que poderia ser feito para livrá-lo deste mal? Segundo o senador, bastaria que o parlamento lançasse mão das prerrogativas que the eram garantidas pelo regime representativo:

\footnotetext{
Mas porque o Corpo Legislativo não toma o seu lugar, não censura esses ministros, não lhes tira o apoio, e os faz cair por força? Eles poderiam recorrer a uma dissolução; porém o povo havia de mandar para a câmara temporária aqueles que houvessem censurado os ministros. ${ }^{77}$
}

Foge aos limites deste artigo analisar se é ou não uma simples coincidência o fato de que efetivamente, apenas alguns dias após este discurso inflamado, o ministério liderado pelo futuro visconde de Itaboraí foi demitido sendo Honório Hermeto Carneiro Leão convidado a formar um novo gabinete. Interessa aqui sobretudo chamar a atenção para a concepção que o senador Manoel de Assis Mascarenhas apresentou acerca da relação entre os poderes do Império. Em suas palavras, cabia ao Poder Legislativo censurar o Executivo pelos excessos cometidos sem qualquer receio de represálias por parte deste, uma vez que mesmo a punição extrema - a dissolução do parlamento - não era capaz de evitar que os que agissem corretamente retornassem através da realização das eleições que obrigatoriamente teriam de ser convocadas.

É importante notar que nesta formulação a fraude e a manipulação do pleito pelo gabinete não parecem compor o quadro apresentado. As eleições são apresentadas pelo senador como um meio efetivo de proteção daqueles parlamentares que cumprissem ciosamente seus deveres, neste caso o de fiscalizar os atos do ministério, criticá-lo e fazer oposição quando entendessem que isto era necessário. Se o governo não cumprisse com seus deveres constitucionais, que sofresse com a oposição implacável do parlamento. Se este fosse dissolvido em nome de sua justa atitude, as eleições se encarregariam de reconduzir a seus postos os que se portassem dignamente.

Para o senador, seria absurda a interpretação segundo a qual a lei de setembro de 1850 habilitava o governo a utilizar-se de todos os meios necessários para introduzir a navegação a vapor no rio Amazonas. Se assim fosse, tornar-se-ia possivel que o governo oferecesse uma subvenção desproporcionalmente grande e um privilégio de cem anos, sem que ninguém pudesse se opor a isto, o que certamente seria inaceitável ${ }^{78}$. E quanto à necessidade de urgência para o início das navegações no Amazonas, dom Manuel afirma que não seria necessário guardar segredo sobre suas causas, como pretendia o ministro, uma vez que já seriam conhecidas de todos: 
A respeito da urgência que há para a navegação do Amazonas, o Sr. Ministro apresentou misteriosamente uma grande razão do Estado. Em primeiro lugar o orador não acha que haja nessa razão de Estado motivo de segredo, porque todos sabem as vistas dos Estados Unidos sobre o Amazonas, e ainda há poucos dias o Sr. Montezuma declarou haver lido no Economist que a América do Norte acabava de fazer um tratado com o Peru pelo qual se tornava livre a navegação desse rio a que temos todo o direito ${ }^{79}$.

Para resolver esta questão, entretanto, não bastaria a assinatura do contrato com Irineu Evangelista de Souza e o início de suas atividades no grande rio. Os meios de que dispunha sua recém fundada companhia seriam pequenos demais para realizar a atividade contratada proveitosamente, e insuficientes para demover os Estados Unidos de qualquer pretensão acerca da região:

\footnotetext{
E depois, pergunto, acaso os dois calhambeques do Sr. Irineu é que irão opor barreira a essa pretensão? Pois a América Inglesa se importa com esses calhambeques, um dos quais é péssimo, segundo dizem? Isso é ridículo, é pueril, não merece resposta. 0 orador descobre cada vez em $\mathrm{S}$. Exa. menos capacidade para ser ministro, pois que nem ao menos mostra que pertence à patrulha $(\mathrm{sic})^{80}$.
}

Não pode ser descartada a hipótese de que existisse alguma rivalidade pessoal entre o senador e o ministro, ou entre aquele e os membros do governo imperial naquele momento. Infelizmente não foi possivel verificar a filiação partidária do senador dom Manoel de Assis Mascarenhas, mas é difícil imaginar que fosse a mesma do ministro Gonçalves Martins, conservador, devido ao teor das acusações dirigidas ao governo. Em todo o caso, o fato de que era possível, da tribuna do Senado ou da câmara dos deputados, formular críticas acerbas ao ministério já indica que, na relação entre estes dois poderes, mais do que uma relação de submissão havia uma de complementaridade, onde a invasão do espaço de um pelo outro poderia gerar atritos de grande magnitude.

Após o segundo discurso de dom Manoel - que, embora inflamado, em nenhum momento apresentou obstáculos sérios ao contrato em discussão (uma vez que o privilégio de exclusividade já havia sido rejeitado pela câmara), o texto foi submetido à votação e aprovado em primeira discussão ${ }^{81}$. Na sessão do dia seguinte, 25 de agosto, foi aprovado em segunda discussão sem qualquer debate ${ }^{82}$. Como o regimento interno previa a necessidade de um intervalo antes que o projeto entrasse em terceira discussão, o senador José Antônio Pimenta Bueno requisitou, em 26 de agosto, a dispensa deste intervalo, para que o texto pudesse ser remetido mais rapidamente à sanção imperial. Concedida a dispensa ${ }^{83}$, o projeto foi rapidamente submetido à votação em terceira discussão na sessão de 27 de agosto e, aprovado sem quaisquer novos debates, foi enviado para ser submetido à sanção imperia| ${ }^{84}$.

Não havia outra alternativa ao governo imperial que não fosse acatar a decisão do parlamento. Na intensa disputa entre os poderes Executivo e Legislativo, o primeiro foi obrigado a recuar. Assim, no relatório do ministro Luiz Pedreira do Couto Ferraz, de 14 de maio de 1854, já se informava solenemente que estavam adiantadas as negociações para o resgate do privilégio de exclusividade de trinta anos na navegação do rio Amazonas: 
85

Relatório do ministério do Império, 14 de maio de 1854, p. 23. Presente em versão digital no site http://www-apps.crl.edu/brazil/ministerial/imperio. Acesso em 13 de junho de 2015.

86

Ibidem, p. 35

87

GREGÓRIO, Vitor Marcos. Uma face de Jano: a navegação..., Op.Cit.
No intuito de corresponder às intenções com que foi promulgado o decreto n. 726 de 3 de outubro do ano passado [1853], trata o governo de resgatar o privilégio concedido por 30 anos de navegação exclusiva à Companhia de que é presidente o comendador Irineu Evangelista de Sousa.

Para este fim recebeu uma proposta para a novação do contrato celebrado entre o empresário e o governo imperial, a qual já foi examinada pelo procurador da Coroa, Soberania e Fazenda Nacional, e pela Seção dos Negócios do Império do Conselho d'Estado. Pende hoje de discussão entre o governo e o dito empresário acerca de certas condições, e o que se resolver definitivamente sobre este objeto ser-vos-á comunicado.

Pretende o governo no novo contrato regular melhor a mesma navegação, e estabelecer a de alguns de seus afluentes, como sejam especialmente o rio Negro e o Madeira, que em grande extensão se prestam á navegação por vapor.

Pretende igualmente dar o devido impulso à fundação de colônias nas margens dos ditos rios, e de outros importantes, a que se comprometeu a Companhia. ${ }^{85}$

Com isso o desentendimento entre os poderes imperiais ficaria resolvido, uma vez que, como afirmou o ministro, "as intenções do poder Legislativo ficarão satisfeitas do melhor modo que era possivel" 86 . No entanto, a obrigatoriedade de resgatar o monopólio demonstrou a disposição de fazer valer, ante as imposições do Executivo, a vontade do poder Legislativo. Desta forma, em 1853 coube ao Legislativo definir as condições de navegação do rio Amazonas. Prevaleceu a doutrina liberal da livre concorrência, o subsídio que viabilizava a navegação por empresa brasileira e a preocupação em colonizar territórios considerados estratégicos para a defesa da soberania nacional. A liberdade de navegação a todos os países só viria anos depois, em 1867, e também teve no parlamento uma importante esfera de decisão ${ }^{87}$.

\section{Conclusão}

Os debates brevemente analisados neste artigo indicam a necessidade de reconsiderar a interpretação historiográfica que concede ao Poder Legislativo uma importância apenas secundária na condução da política imperial. Os discursos proferidos, o resultado das votações realizadas (com suas consequências práticas para os projetos em discussão), bem como a postura dos ministros Joaquim José Rodrigues Torres e Francisco Gonçalves Martins perante o parlamento (e dos membros deste para com eles) parecem apontar para a necessidade de um efetivo esforço de composição dos membros dos gabinetes para com as posições contrárias apresentadas tanto na Câmara dos Deputados quanto no Senado. 0 sistema representativo imperial não era algo restrito apenas às páginas da Constituição ou aos lábios dos que afirmavam atuar em suas construção. As discussões acima apresentadas permitem propor que ele fazia parte da prática política cotidiana do Brasil monárquico, pelo menos nos dois momentos analisados, mas muito provavelmente também nos dez anos que os separam. Se existiam elementos que colocavam em dúvida a legitimidade desta prática, ela nem por isso deixava 
de existir e de possuir acentuada importância nos processos políticos de meados do oitocentos.

Embora ministros pertencentes ao núcleo conservador, portanto com ascendência sobre grande parte dos parlamentares que compunham as legislaturas de 1843 e de 1853, tenham efetivamente apoiado a apresentação de propostas e implementado políticas que entendiam importantes para 0 desenvolvimento do pais, eles só poderiam de fato concretizá-las com a aprovação expressa do parlamento demonstrada por debates e votações no plenário. Não quero, com isso, propor que eles não tivessem importância neste processo. Com certeza tinham. Apenas indico que, se esta importância era grande, ela não parece bastar para permitir aos membros do Poder Executivo resolver as questões aqui analisadas por si sós, única e exclusivamente do modo que julgassem mais conveniente. Era necessário que se propusessem a convencer deputados e senadores da justiça de suas propostas, a negociar com eles quando isso se mostrasse necessário, a ceder e recuar quando as chances de vitória se tornassem nulas. Isso mesmo que contassem com ampla maioria de copartidários no plenário de ambas as casas legislativas. Práticas plenamente coerentes com o sistema político que parlamentares e ministros sempre afirmaram estar trabalhando para construir, qual seja, um sistema representativo inspirado nas experiências inglesa e francesa pós-revolucionárias.

\section{Referências Bibliográficas}

BARBOSA, Silvana Mota. 0 Conselho de Ministros no Império do Brasil. Locus: revista de História, Juiz de Fora, vol. 13, n. 1, p. 52-62, 2007;

BARMAN, Roderick J. Brazil. The forging of a nation (1798-1852). Stanford: Stanford University Press, 1988;

BARMAN, Roderick J. Imperador cidadão. São Paulo: Editora Unesp, 2012;

BELOTO, Divonzir A criação da província do Paraná: a emancipação conservadora. Dissertação (Mestrado). Pontifícia Universidade Católica, São Paulo, 1990;

CARVALHO, José Murilo de. A construção da ordem: a elite politica imperial. Teatro de sombras: a política imperial. Rio de Janeiro: Civilização Brasileira, 2011;

Divonzir Beloto. A criação da província do Paraná: a emancipação conservadora. Dissertação (Mestrado). Pontifícia Universidade Católica, São Paulo, 1990;

DOLHNIKOFF, Miriam; MAIA, Francisleide; SAEZ, Hernán Lara; SALES, Pedro Paulo Moreira; GREGÓRIO, Vitor Marcos. Representação política no Império: crítica à ideia do falseamento institucional. In: LAVALLE, Adrian Gurza (org.). O horizonte da política: questões emergentes e agendas de pesquisa. São Paulo: Editora Unesp: CEBRAP: CEM, 2012, pp. 97-141;

ESTEFANES, Bruno Fabris. Conciliar o Império. 0 marquês do Paraná e a politica imperial, 1842-1856. São Paulo. Annablume. 2014;

FAORO, Raymundo. Os donos do poder. Rio de Janeiro: Globo, 1987;

GREGÓRIO, Vitor Marcos. Dividindo as províncias do Império: a emancipação 
do Amazonas e do Paraná e o sistema representativo na construção do Estado nacional brasileiro (1826-1854). 486f. Tese (doutorado em História Econômica). Faculdade de Filosofia, Letras e Ciências Humanas, Universidade de São Paulo, São Paulo, 2012;

GREGÓRIO, Vitor Marcos. Uma face de Jano: a navegação do rio Amazonas e a formação do Estado brasileiro (1838-1867). São Paulo: Annablume, 2012;

HOLANDA, Sérgio Buarque de. 0 poder pessoal. In: HOLANDA, Sérgio Buarque de (dir.). História Geral da Civilização Brasileira, Tomo II, Vol. 7 Do Império à República. Rio de Janeiro: Bertrand Brasil, 2008;

HÖRNER, Erick. Guerra entre pares - a "Revolução Liberal" em São Paulo, 18381844. Dissertação (Mestrado). Faculdade de Filosofia, Letras e Ciências Humanas, Universidade de São Paulo, São Paulo, 2005;

JAVARY, João Alves Loureiro (Barão de). Organizações e programas ministeriais: regime parlamentar no Império. Rio de Janeiro. Arquivo Nacional, 1962;

MATTOS, IImar Rohloff. O tempo saquarema: a formação do Estado imperial. São Paulo. Hucitec, 2004;

MEDEIROS, Fernando Sabóia de. A liberdade de navegação do Amazonas (relação entre o Império e os Estados Unidos da América). São Paulo: Companhia Editora Nacional, 1938;

PEREIRA, João Félix. Chorographia do Brazil. Lisboa: Imprensa de Lucas Evangelista, 1854;

SANTA CRUZ, Fábio Santiago. Em busca da conciliação: ideias políticas no parlamento do império do Brasil (1831-1855). Tese de Doutorado. Brasilia. Universidade de Brasília, 2008;

SÃO VICENTE, Marquês de. Direito Público Brasileiro e Análise da Constituição do Império. In: KUGELMAS, Eduardo (org.). José Antônio Pimenta Bueno, Marquês de São Vicente. São Paulo: Editora 34, 2002;

URUGUAI, Visconde do. Ensaio sobre o Direito Administrativo, in: CARVALHO, José Murilo de (org.). Paulino José Soares de Sousa, Visconde do Uruguai. São Paulo: Editora 34, 2002;

VASCONCELOS, Zacarias de Góis e. Da Natureza e Limites do Poder Moderador. In: OLIVEIRA, Cecília Helena de Salles (org.). Zacarias de Góis e Vasconcelos. São Paulo: Editora 34, 2002. 